\title{
PEAT SOIL IMPROVEMENT WITH BAMBOO REINFORCEMENT TECHNOLOGY: A REVIEW
}

\author{
Faizah Md Talib ${ }^{1},{ }^{*}$ Habib Musa Mohamad ${ }^{2}$, Muhammad Nursyahrain Mustafa ${ }^{3}$ \\ ${ }^{1,2,3}$ Faculty of Engineering, Universiti Malaysia Sabah, Sabah, Malaysia. \\ *Corresponding Author, Received: 05 July 2021, Revised: 12 Nov. 2021, Accepted: 01 Dec. 2021
}

\begin{abstract}
Construction of road or building on soft soil, especially on peat soil, is the most challenging condition where there are consequences that engineers may have faced. Peat has excellent water-holding characteristics, highly fibrous due to the presence of a lot of decomposed materials and organic matter, which makes it highly compressible, weak at shear strength, and low in bearing capacity. This characteristic makes it unsuitable for use as foundation or sub-grade since it would have a large impact on deformation and settlement if not treated very well. Due to the excellent effects, soil reinforcement has been seen as a relevant method in various infrastructural projects in recent years since this technique is the most practical application to improve the strength and stiffness of peat soil by using various methods, including bamboo technology. This paper highlights some of the alternative methods in peat soil reinforcement technology. It combines several techniques based on the floating concept bamboo insights that effectively distributed the load on the embankment over the peat soil. In this strategy, it is observable to reduce the impact of deformation and settlement on peat soil.
\end{abstract}

\section{Keywords: Peat soil, Index Properties, Reinforcement, Deformation, Settlement}

\section{INTRODUCTION}

Peat soil can be regarded as problematic soil due to its physical properties, which have high moisture content and accumulation of organic matter in peat soil. Since peat is a type of soil that contains a lot of dead organic matter, it is formed due to a limited supply of oxygen under waterlogged or poorly drained soil. The factors that cause peat accumulation are strongly interrelated. Due to differences in climate, soil types, and plant types, various peatlands developed and formed $[1,2]$. Compared to other inorganic soils such as clay and sandy soils, which are made up only of soil particles, this particular aspect also made the peat shows its own distinctive geotechnical properties [3].

Nowadays, new development over peat soil is increasing due to the lack of space and suitable land for building infrastructures, highway construction and various type of developments. The dominant problems of peat soil in foundation construction are generally discussed due to intrinsic characteristics such as low shear strength, extremely high natural moisture content, high compressibility and water holding capacity, low specific gravity, and low bearing capacity [4]. On the other hand, laterite is used as embankment material on peat soil.

Correspondingly, the irregular behavior of peat soil perceptible to be solved by using soil improvement methods such as soil replacement, water removal, site strengthening, thermal and geosynthetics. The water removal method can be divided into four categories which are trenching, electroosmosis, pre-compression without vertical drain, and pre-compression with vertical drain. In Malaysia, pre-compression with vertical drain method is popular to remove the water from the soil [5].

In this regard, understanding and determining the laboratory element of testing is essential to represent or mimic the field conditions to simulate an important role in characterizing soil behavior. On top of that, the selection of the reconstituted method is particularly important to gain uniformity and repeatability specimens that are capable of simulating the study area of the ground improvement method.

\section{RESEARCH SIGNIFICANCE}

The significance of this research project was to explore the new potential of the reinforcement method using the floating concept and its relationship with bamboo applications. Bamboo application in road embankment is the most common way in which a settlement in the embankment area can be stabilized with an internal potential of this application. This research project helps to improve the fundamental knowledge in preparing reinforcement works on peat soil.

The findings of this study will directly benefit researchers and engineers in regaining the stability and strength of infrastructure on peat soil. Significantly contributed at the core of impact identification, prediction, evaluation and decisionmaking in settlement impact. The establishment of 
general assessment criteria and methodology is a specific indicator for each research domain in peat soil. This model of research in the intellectual capital will result in practical training and application methods for technological domains, which is intensively generating products with knowledge and the ability to produce reliable methods and applications.

\section{CHARACTERISTICS OF PEAT SOIL}

Peat is a mixture of fragmented organic materials form, where less supplied oxygen prevents the natural microorganisms from decomposing the dead plant materials. Thus, peat is considered unsuitable for supporting foundations in its natural state. Peat represented an extreme form of soft soil. It is an organic soil, which consists of more than $75 \%$ of organic matter [1]. The organic content of peat is basically developed with plant fiber which is the rate of accumulation is faster than the rate of decay. The fiber content of peat differs from location to location due to factors such as the origin of fiber, temperature, and humidity [7].

Based on USDA (soil Taxonomy) and [6], the definition of peat soil depends on the purpose or the field of application as shown in Table 1 where the purpose of application shown from agriculture and soil science perspectives, peat is defined with organic content more than $20 \%$ and $35 \%$ respectively. Meanwhile, for the geotechnical engineering purpose, the organic content less than $75 \%$ is known as organic soil, otherwise is known as peat [6].

Table 1 Definition of peat soil with purpose.

\begin{tabular}{ccc}
\hline $\begin{array}{c}\text { Purpose of } \\
\text { application }\end{array}$ & Definition & $\begin{array}{c}\text { From } \\
\text { reference }\end{array}$ \\
\hline $\begin{array}{c}\text { Geotechnical } \\
\text { engineering }\end{array}$ & $\begin{array}{c}\text { Organic content }< \\
75 \%=\text { organic soil } \\
\text { Organic content }>\end{array}$ & ASTM \\
& $75 \%=$ peat & \\
& & \\
& & \\
Agriculture & Organic content $>$ & USDA (Soil \\
& $20 \%=$ peat & Taxonomy) \\
Soil science & Organic content $>$ & USDA (Soil \\
& $35 \%=$ peat & Taxonomy) \\
\hline
\end{tabular}

There are about thirty million hectares of peat soil covered around the world, with Canada and Russia having the largest distribution of peat soil [6]. Most notable are the largest peatland on the islands of Borneo are parts in Indonesia, Malaysia and Brunei. However, there are also significant occurrences in other parts of Indonesia, Malaysia, Vietnam, Thailand and the Philippines [9].
Table 2 Distribution area of peat in Malaysia

\begin{tabular}{cc}
\hline State & $\begin{array}{c}\text { Total Area of Peat } \\
(\mathrm{Ha})\end{array}$ \\
\hline Johor & 143,974 \\
Pahang & 164,113 \\
Selangor & 164,708 \\
Perak & 69,597 \\
Terengganu & 84,693 \\
Kelantan & 9,146 \\
Negeri Sembilan & 6,245 \\
Federal Territory & 381 \\
Sabah & 116,965 \\
Sarawak & $1,697,847$ \\
Total & $2,457,730$ \\
\hline
\end{tabular}

In Peninsular Malaysia, Selangor recorded the highest distribution area of peat soil, and the smallest distribution area was recorded by Negeri Sembilan. Johor has recorded the third largest area of peat distribution after Pahang and Selangor, with a total area of 143974 hectares. However, the distribution of peat in Sarawak has recorded the largest distribution of peat area in Malaysia with 1697847 hectares, followed by Peninsular Malaysia with 642918 hectares and Sabah with 116965 hectares respectively. Overall, the total distribution area of peatland in Malaysia is about 2457730 hectares.

Sabah supports the second largest area of peat in Malaysia, about $4.76 \%$ or 116,965 ha, according to wetland International, Malaysia [10]. Peatlands in Sabah were growing as options for development and converted to productive use. In Sabah, $2 \%$ or 29,000 ha of oil palm plantations occur on peatland. The undisturbed and disturbed peatland in Sabah summed overall $62 \%$ or 714,000 ha [11].

\subsection{Beaufort, Sabah Peat Soil Formation}

As an introduction to the Sabah peat soil distribution, this study was initiated in Lumadan and Klias Peninsula - peat swamp forest at Beaufort, Sabah. In the latitude 5.284554 and longitude 115.665736. Beaufort, Sabah becomes exhibit location. This location is well known as a peat deposit area based on some of peat swamp areas are well-recognized locations as peat deposited in Sabah [56].

The classification and observation peat have followed 10 degrees of humification from $\mathrm{H} 1$ to $\mathrm{H} 10$ in the Von Post Scale. Lumadan is in the Bukau Api-Api cluster area, where peat deposits redundantly occurred. In Lumadan, it forms part of the Beaufort District, Sabah. It accounted for the largest portion of the area in Beaufort where mostly peat deposit occurred along the Klias Peninsula. 
Table 3 Tabulated Index properties in another researcher in Malaysia

\begin{tabular}{|c|c|c|c|c|c|c|c|}
\hline $\begin{array}{c}\text { Researcher } \\
\& \\
\text { Properties }\end{array}$ & $\begin{array}{c}\text { Islam } \\
\text { and } \\
\text { hashim } \\
\text { 2010a, b }\end{array}$ & $\begin{array}{l}\text { Duraisamy } \\
\text { et al., } 2020\end{array}$ & $\begin{array}{l}\text { Sa'don } \\
\text { et al } \\
(2014)\end{array}$ & $\begin{array}{l}\text { Azrul et al } \\
\text { (2016) }\end{array}$ & $\begin{array}{c}\text { Adnan \& } \\
\text { Habib } \\
\text { (2016) }\end{array}$ & $\begin{array}{l}\text { Nurul } \\
\text { et } a l \\
(2020)\end{array}$ & $\begin{array}{l}\text { Habib } \\
\text { et al } \\
(2021)\end{array}$ \\
\hline Location & $\begin{array}{c}\text { West } \\
\text { Malaysia }\end{array}$ & $\begin{array}{c}\text { West } \\
\text { Malaysia }\end{array}$ & $\begin{array}{c}\text { Batu } \\
\text { Kawa, } \\
\text { Sarawak }\end{array}$ & $\begin{array}{c}\text { Batu Kawa } \\
\text { Sarawak }\end{array}$ & $\begin{array}{l}\text { Beaufort, } \\
\text { Sabah }\end{array}$ & $\begin{array}{c}\text { Beaufort, } \\
\text { Sabah }\end{array}$ & $\begin{array}{l}\text { Beaufor } \\
\text { t, Sabah }\end{array}$ \\
\hline $\begin{array}{c}\text { Von Post } \\
\text { Classification }\end{array}$ & $\begin{array}{l}\mathrm{H} 4-\mathrm{H} 5 \\
\text { (Hemic) }\end{array}$ & $\begin{array}{l}\mathrm{H} 4-\mathrm{H} 5 \\
\text { (Hemic) }\end{array}$ & $\begin{array}{l}\mathrm{H} 4 \text { - H5 } \\
\text { (Hemic) }\end{array}$ & $\begin{array}{c}\text { H5 } \\
\text { (Hemic) }\end{array}$ & $\begin{array}{c}\text { H6 } \\
\text { (Hemic) }\end{array}$ & $\begin{array}{l}\text { H6-H7 } \\
\text { (Sapric) }\end{array}$ & $\begin{array}{c}\mathrm{H} 4 \\
\text { (Hemic) }\end{array}$ \\
\hline $\begin{array}{c}\text { Moisture } \\
\text { Content (wN) } \\
(\%)\end{array}$ & $414-674$ & $198-417$ & $607-926$ & $607-926$ & $\begin{array}{c}489.09- \\
985.30\end{array}$ & $\begin{array}{l}630.35- \\
673.99\end{array}$ & 682 \\
\hline $\begin{array}{l}\text { Liquid Limit, } \\
\text { LL }(\%)\end{array}$ & 208.39 & $202.3-220.7$ & $252-261$ & $252-261$ & 256.13 & $158-171$ & $\begin{array}{c}200- \\
500\end{array}$ \\
\hline $\begin{array}{c}\text { Plasticity } \\
\text { Index, PI (\%) }\end{array}$ & - & - & $97-100$ & $97-100$ & - & - & م \\
\hline $\begin{array}{c}\text { Organic } \\
\text { Content, OC } \\
(\%)\end{array}$ & $\begin{array}{l}88.61- \\
99.06\end{array}$ & 41-99 & 95 & 95 & $\begin{array}{l}53.97- \\
95.51\end{array}$ & $\begin{array}{c}56.63 \%- \\
99.42 \%\end{array}$ & 98.430 \\
\hline $\begin{array}{c}\text { Fiber } \\
\text { Content, FC } \\
(\%)\end{array}$ & $\begin{array}{l}90.25- \\
90.49\end{array}$ & $31-77$ & 50.3 & 50.3 & 65.22 & $\begin{array}{c}61.28 \%- \\
67.03 \%\end{array}$ & 18 \\
\hline $\mathrm{pH}$ Value & 3.51 & $3-5$ & $3.3-3.9$ & $3.3-3.9$ & $4.0-4.6$ & $3.0-3.5$ & 4.25 \\
\hline $\begin{array}{c}\text { Specific } \\
\text { Gravity (Gs) }\end{array}$ & $0.95-1.34$ & $0.95-1.34$ & $1.11-1.34$ & $1.11-1.34$ & 1.34 & $1.22-1.57$ & 1.42 \\
\hline
\end{tabular}

Lumadan peat has high fiber and organic content and is classified as hemic peat [12]. The studied peatland covers an area of 15 ha in the private property in a commercial agricultural plantation adjacent to the Klias Forest Reserve (Peat Swamp) and $13 \mathrm{~km}$ away from the Beaufort township area. In Beaufort itself, there are few protected peats swamp forests from Klias Forest Reserve (KFR), Kampung Hindian Forest Reserve (KHFR) and Pulau Nabahan Forest Reserve (PNFR). A high percentage of decomposed material and the appearance of peat exhibits poor consolidation properties with increased compressibility and low shear strength [13].

Generally, Beaufort peat soil is dark brown to black in color and some area indicates hickory to umber color [7]. The physical of peat are spongy and fragile textures. The thickness of peat in Klias, Beaufort was discovered between $2 \mathrm{~m}$ to $7.5 \mathrm{~m}$ depth [14].

\subsection{Index properties of Peat Soil}

The following characteristics are suggested [24] and [25] to describe the index properties of peat soil.
They are influenced by the main component of the formation, such as mineral content, organic content, moisture and air. When one of these components changes, it will result in changes in the whole physical properties of peat. The index properties of peat data studied from the past researchers in Malaysia and tabulated in Table 3.

Index properties of peat soil are highly affected by the porosity and the distribution of the pore size. Both parameters are related to the distribution of peat size. The degree of decomposition affects the porosity of peat, and the porosity is influenced by the particle size and structure of the peat [20].

With an increase of the decomposition level, thus it tends to change the particle size of organic matters and decreases properties of peat, which is color, and odor, water content, degree of humification, fiber content, liquid limit and plastic limit, principal plant component namely coarse fiber, fine fiber, amorphous granular material and woody material, grain size distribution, density, specific gravity and Atterberg limits. 


\subsubsection{Degree of decomposition}

Hydrologic characteristics of peat soil, such as water storage and rate of water movement, depend on a large degree of the porosity and pore-size distribution of the peat material.

These are, in turn, related to the particle-size distribution and structure of the soil. In peat materials, the particle size, structure, and resulting porosity are determined by the state of decomposition [54]. It can be related to the proportion of humification product of the entire peat substance. The definition continues with a scale of one to ten, the Von Post humification method.

\subsubsection{Water content}

The water content is the most important criteria property for peat soil. The value of water content depends on its origin, degree of decomposition and the chemical composition of peat [20]. Generally, peat has extremely high natural water content due to its ability to hold water capacity. According to the previous study, the high natural moisture content of peat soil had reached (up to $800 \%$ ) [3].

East Malaysian peat had moisture content ranging from 200 to 2200 percent [21], which is quite different from that for clay and silt deposits which rarely exceed $200 \%$. Sarawak had reached up to $1096.59 \%$ [22]. Meanwhile, Sabah has recorded the water content in peat that almost $1000 \%$ [23]. The water content of fibrous peat generally is extremely high [27].

It is because fibrous peat holds a considerable amount of water as its coarse organic particles are generally very loose and the organic particles themselves are hollow and largely full of water [20]. It shows that the soil is slightly decomposed peat which, when squeezed, releases very muddy dark water.

\subsubsection{Specific Gravity}

The specific gravity of peat is greatly affected by its composition and percentage of the inorganic component. It is related to the degree of decomposition and mineral content of peat. Higher specific gravity indicates a higher degree of decomposition and higher mineral content. The determination of the specific gravity of the peat soil sample uses a small pycnometer method according to BS 1377: Part 2: 1990. Specific gravity lies in the range from 0.9 to 1.88

\subsubsection{Organic Content}

Organic matter influences the physical, chemical, and biological properties of peat soils. Some of the properties are influenced by organic matters, including the soil structure, soil compressibility and shear strength. According to BS 1377: Part 3: 1990, the organic content will determine the mass loss on ignition. According to [27] and [28] that have conducted an investigation on shrinkage behavior of peat soil in Parit Nipah, Johor. The value percentage of shrinkage between [27] and [28] are 7-29 and 33.09-34.77.

The value of shrinkage is different is because the index properties of both soils are different such as their natural water content, which is both values is $791 \%$ and $658-701 \%$. The value of the specific gravity for both researchers is also different, which is 1.88 and 1.43-1.62. Besides that, the percentage of organic content for both researchers also got a different value. Both have a value of $78.76 \%$ and 75.45-89.87. With this different value of index properties, it is possible for both researchers to have a different value of shrinkage of peat soil.

\section{IMPROVEMENT METHOD FOR PEAT SOIL STABILITY}

Since peat has contains an excessive amount of water, which is the main factor contributing to the characterization of high permeability and extremely low shear strength or bearing capacity. This weak characteristic can have an impact on geotechnical problems around the area of sampling settlement, stability, in situ testing, stabilization and construction [29]. For a successful design, construction, and good performance of structures on such soil, it is paramount to predict its geotechnical behavior in terms of settlement, shear strength and stability, with respect to time [1][23].

Several researchers have proposed soil improvement and different construction techniques to solve and manage construction on peat soils. Some improvement method on peat soil is different for each depth category of peat, as highlighted [25]. The excavation, peat replacement, and peat displacement are practically up to the $5 \mathrm{~m}$ depth [1]. For the depth $3 \mathrm{~m}$ to $10 \mathrm{~m}$, normally, the method of the sand drain, lightweight fills and stone column is used [1]. The traditional method of avoiding and replacing peatlands is impractical since the number of residents of the population is increasing.

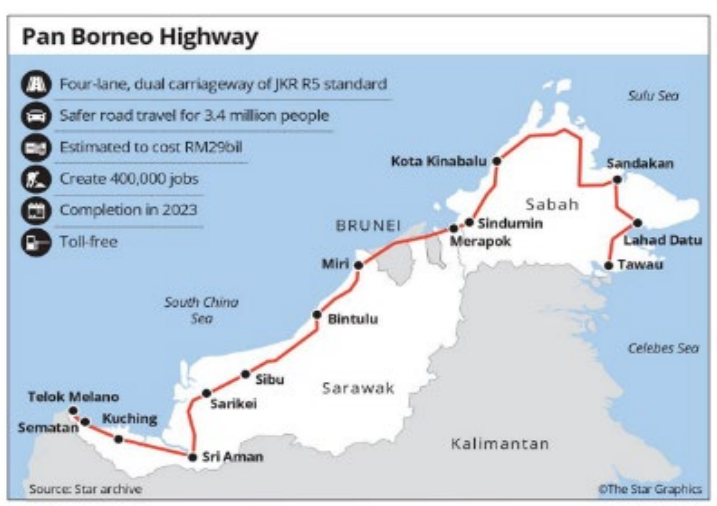

Fig. 2 The route of Pan Borneo Road connecting two state Sabah and Sarawak.[58] 
The population growth is equivalent to the growing need for accommodation, which leads to the high demand for land. The Pan Borneo Highway (Figure 2) is one of the examples of the development carried out on peat soil for road subgrade construction that needs intensive care to design and construct to avoid the road crossing numerous swamp areas on poor soil conditions. The main issue of the highway design is the weak soil of the road subgrade.

\subsection{Modes of Common Failure}

When loading is applied on the ground, depending on the peat conditions, settlements and deformation happen in many different modes, including tipping, differential, and uniform settlements. Excessive settlers have such an adverse effect on the durability and smoothness of roads and highways. As seen in Figure 5, this can be seen as an extreme longitudinal pavement cracking and poor driving conditions. Due to high natural moisture content, high compressibility, low bearing volume, and medium to low permeability, this is one of the most common causes of road collapse

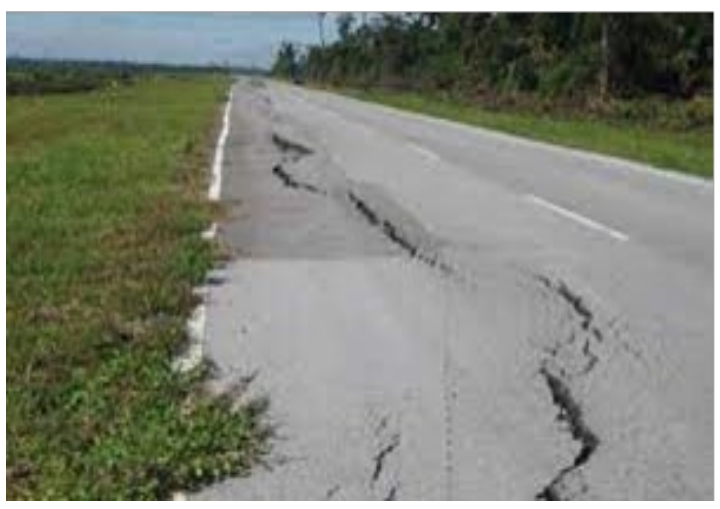

Fig.5 Failure Road on Kg Sungai Bidut, Sarawak Road [30]

\subsection{Method of Road Construction 'Peat left in place'}

Another popular method is applied in construction on peat is categorized as 'peat left in place' that utilizes the underlying peat as a loadbearing layer [19]. Table 4 shows the various method of soil improvements in 'peat left in place' technique.

However, for this paper, the concept and principle of the reinforcement method are highlighted, which is deemed to most of the practical techniques in applications for peat soil improvement related to the strength and stiffness of soil by using various methods. The road constructions on peat soil have been around started since $4000 \mathrm{BC}$.

\begin{tabular}{|c|c|}
\hline Technique & Method \\
\hline $\begin{array}{l}\text { Strength } \\
\text { Improvement }\end{array}$ & $\begin{array}{ll}\text { - } & \text { Preloading } \\
\text { - } & \text { Surcharging } \\
\text { - } & \text { Stage construction }\end{array}$ \\
\hline $\begin{array}{l}\text { Load } \\
\text { Modification }\end{array}$ & $\begin{array}{ll}\text { - } & \text { Profile lowering } \\
\text { - } & \text { Pressure berms } \\
\text { - } & \text { Slope reduction } \\
\text { - } & \text { Lightweight fill } \\
\text { - } & \text { Offloading }\end{array}$ \\
\hline \multicolumn{2}{|c|}{$\begin{array}{l}\text { Vertical Drainage } \\
\text { Piling }\end{array}$} \\
\hline & ilization \\
\hline
\end{tabular}

Table 4 List of peat left in place method

\subsection{History Traditional Reinforcement}

The Corduroy (Figure 6) is one of the alternative methods that communities used to access the road teen primitive communities or as accesses to local peat workings. The Corduroys are designed to distribute the load from the traffic and embankment over a wider area. Compared to these reinforcing results in this early era, it seems that heavy Corduroys are more effective than light Corduroys in distributing the load.

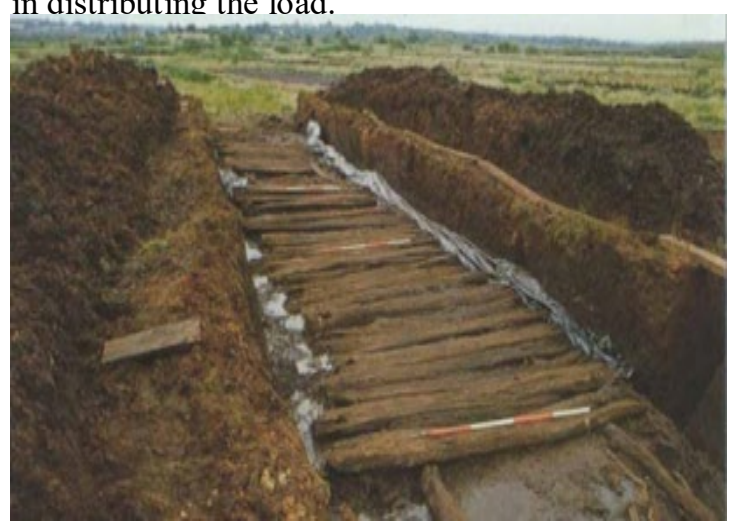

Fig.6 Trackways through Time, Archaeological Investigations on Irish Bog Roads [19].

The term reinforced soil is commonly referred to as a composite construction material formed by combining soil and reinforcement. Although it is called 'systematically strengthened ground,' while the latter is termed 'randomly dispersed fiber strengthened ground' or 'fiber strengthened ground. Reinforced soils have been studied and practiced crudely since ancient times; in civil engineering applications, they have been applied more often since the modern type of soil reinforcement developed in 1966 [31]. 


\section{REINFORCEMENT METHOD FOR PEAT}

There are six groups of reinforcement that are successfully used as reinforcement material such as metal rods or strips, concrete, glass fiber, wood, rubber, aluminum, and thermoplastic. [32] Geotextile, geogrids, timber, or bamboo mattresses is a type of method of non-biodegradable fabrics reinforcement. It can be used to separate granular embankment fill from the soft subsoil on which it is being placed and for tensile reinforcement to increase the overall stability of the embankment [1][16].

\subsection{Timber, Bakau and Bamboo Mattress.}

For many years, reinforcement of soil with timber, mangroves and bamboo has been used in construction embankments on soft soil. The practical uses of them are many, timber and mangrove usually used for raft piled to support of shallow sliding foundation [33] and soil nailing. Bamboo is a well-known traditional building material that grows abundantly in tropical and subtropical places across the world.

Bamboo mattresses were found to be effective and successful as reinforcement when the combination of bamboo and geotextile was installed on the peat area. In 1990, an earlier study conducted $[35,36]$ successfully demonstrated the effectiveness of bamboo mattresses for lowering groundwater levels and preventing lateral movement by isolating the original muddy soil like peat over embankment in the Kinta valley during that time.

The geotextile is unable to use independently direct on the peat area without the roll sinking into the incredibly soft material. It tore when soil or sand filled up into embankment area. Thus a geotextile placed over a bamboo fascine was found to be the most effective method of overcoming the said problems.

The potential of Bamboo-geotextile composite (BGC) is attracting the interest of researchers $[32,39,40,41,42,43,44,45]$ to study more about the capabilities of bamboo form in reinforcement systems. Studies have been conducted on the behavior and have come out with the idea of other combinations with bamboo mattresses [45].

[45] analyzed the bamboo-geotextile composite (BGC) in terms of bearing capability, as indicated in Figure 7, parallel with the square design. The employment of BGC in strengthening the system is able to discover and disseminate the burden further less than the use of geotextiles alone or bamboo grids alone. When bamboo is used in a square grid layout, it can be generated an interlocking pattern that increases the rigidity of bamboo, which equally distributes vertical pressure and reduces differential and total settling.
Its central portion supports the embankment against downward displacement by mobilizing the tensile strength of transverse slopes, and the compressive strength of longitudinal bamboo ribs is able to prevent a catastrophic failure. The geotextile layer acts as a separator and filter between the infill materials with the soft clay layer. It also functions as a "tension layer" between bamboo stems by reducing local stresses in soft soils. The shear strain level in monotonic strength decreases lower than its initial strength [46].

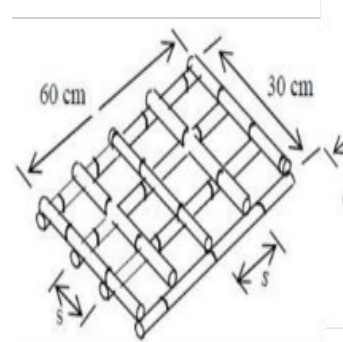

a) Bamboo square pattern

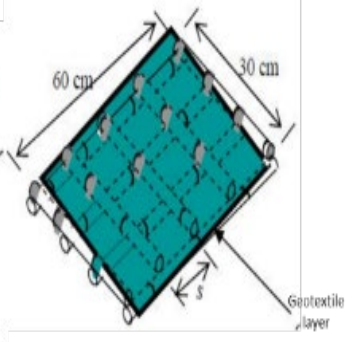

b) composite square pattern
Fig.7 Bamboo and bamboo-geotextile composite reinforcement models pattern [45]

Reinforcement method by using bamboo mattress also known as the "Bamboo - Geotextile Buoyant Platform System" or "Geobamtile System." This innovative approach, which was researched and developed at the university by [48], and was successfully commercialized in the construction industry.

The purpose of design is to solve a critical contemporary civil engineering problem of supporting very heavy construction safely over deep soft subgrade without attracting excessive settlements in due course.

In practical terms, the Geobamtile system is simply a superbly big 'raft foundation' constructed inexpensively by tying together rounded matured bamboo culms each of $5 \mathrm{~m}$ length approximately by galvanized iron wires into a grid network, as seen in Figure 8 and Figure 9. It is noteworthy that the research concept is similar to other researchers $[35,36,39]$ on the use of bamboo with geotextile are solely for separation between the problem soil and embankment, but the difference of this reinforcement is using two layers of the bamboo mattress.

The method and concept were found in simple well established in affordable surface areas for efficient stress distribution with the exceptional bending and buoyancy capabilities of bamboo culms. This was seen significantly reduced and attenuated the original vertical applied stress on the soft bearing subgrade below. Figure 10 and 11 shows the projects that applied this method. 


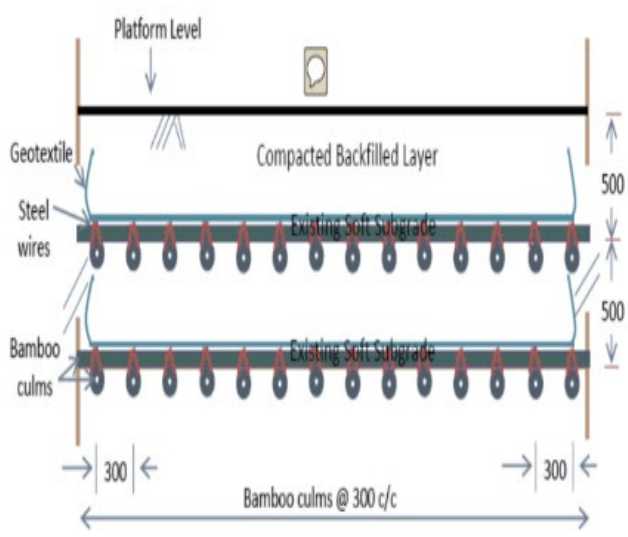

Fig. 8 Cross Section of Bamboo-geotextile Grid Frame Raft Base [48]

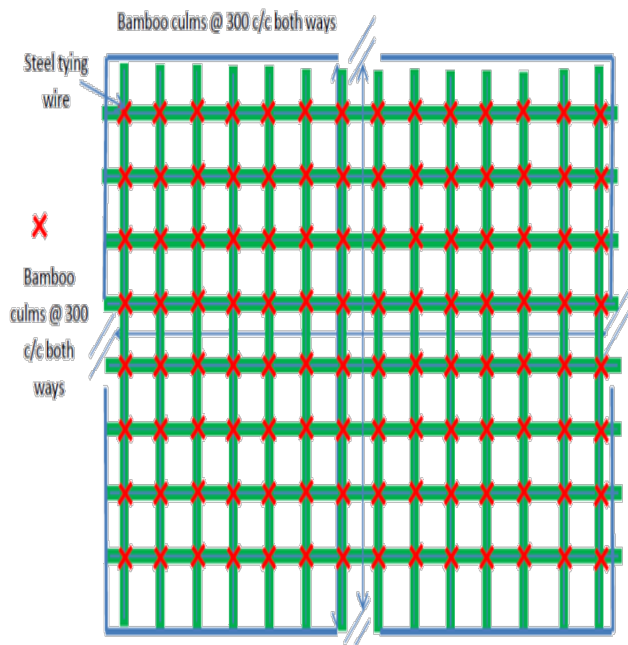

Fig.9 Plan view of Bamboo Grid Frame Raft Base without Geotextile Atop [48]

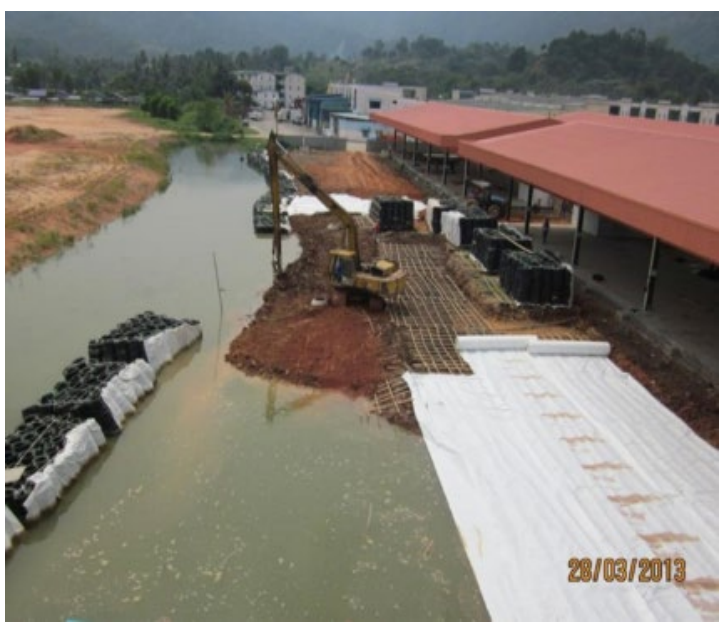

Fig. 10 Houses to be built over soft peat devoid of foundation but supported on 'geobamtile' system [48]
Meanwhile, [40][41][42] have studied the behavior of bamboo reinforcement by adding the layer of bamboo mattress at the beneath of embankment on peat soil. The results shows that the bamboo grid is able to reduce the settlement by adding the layers.

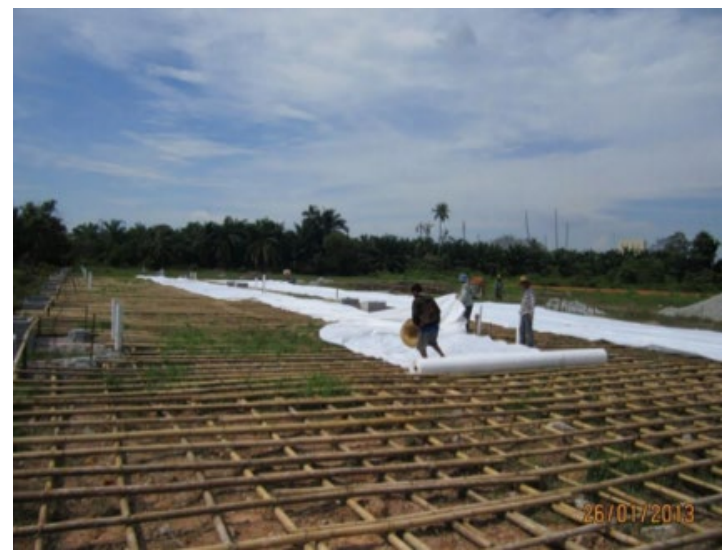

Fig.11 Avoiding the abrupt failure of constructed structure during the project [48]

The common practice of bamboo is to use in soft clay as a pile for coastal revetment for protecting high-fill reclamation work by sea waves, since it longer and stronger. The bamboo pile with bamboo pile raft system has been proven that can increasing the soil bearing capacity, reduce differential settlement of soft clay by use clusters of bamboo of 3-7 pieces tied together to make a big pile. The raft is also made of several sheets (3-7 layers) to make a strong mattress [35]. Thus, the implementation of reinforcement method using bamboo mattress with pile bamboo for peat soil are investigated [42], this research is expecting to reduce the settlement and deflection of bamboo grid and pile due to the load of embankment and in the end can increase the bearing capacity of peat soil. Figure 12 shows the illustrated of embankment model in laboratory scale study. The modeling of embankment was arrange using pieces of iron to form a trapezoid over a bamboo grid and a bamboo pile as a reinforcement of peat soil.

The research monitors the movement of soil with grid bamboo reinforcement alone compare combination of bamboo grid with pile. Each testing was conducted gradually with the addition of a load applied, 1 layer each day until the fifth day. On the sixth day, there is reduced load from the fifth to the first layer Fig 12 and Fig 13 and Fig 14 is the data result of research. Due to the use of bamboo piles, the bamboo grid deflection under the embankment looks smaller as the bamboo pile spacing is used as a reinforcement. Thus, the installation of bamboo piles combined with bamboo grids is able to reduce the settlement and the deflection of the bamboo grid. 


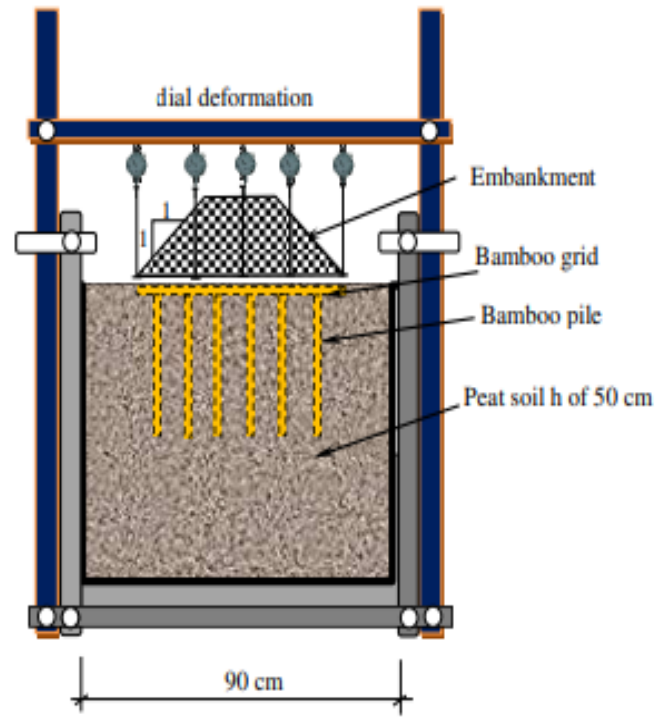

Fig. 12 Testing scheme in the laboratory [42]

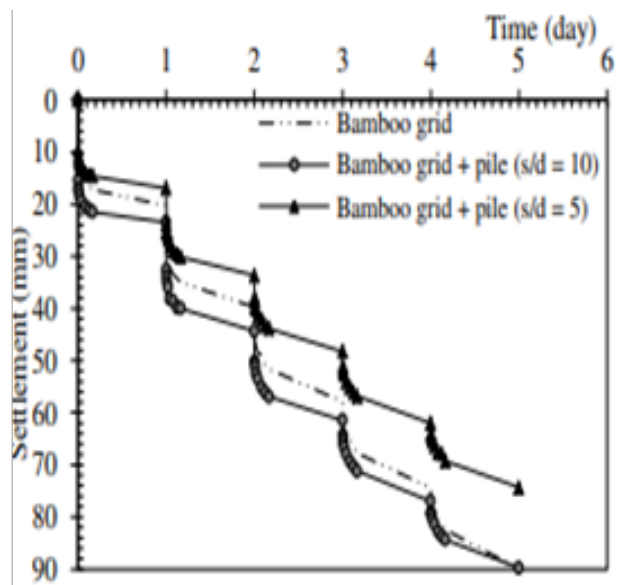

Fig.13 Relationships between time vs settlement

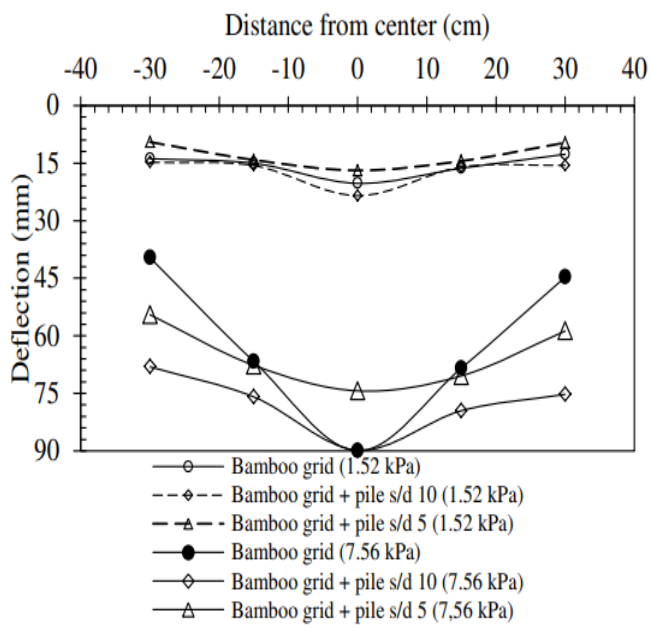

Fig.14 Deflection in the cross-section direction of embankment [42]

\section{CONCLUSIONS}

Although, bamboo shows a lot of potential in various applications. Bamboo has a weakness since bamboo is a biodegradable material and has pathologies, such as the susceptibility to fungi and insect attack, lignin degradation when exposed to UV rays, temperature and humidity variation, low shear resistance and geometric imperfections [48].

These factors are able to reduce the durability and strength of bamboo when both isolated and combined. It generates cracks along the longitudinal fibers of the material, which induces premature flexure-compression failure when subjected to compression load [48]. In the end, it becomes a part of a decomposed plant fragment.

To overcome the solution, by refer in literature review of floating road concept and implantation reinforcement method by another research. It can be concluded that bamboo gets the buoyancy force since bamboo has a hollow void part, where the air is trapped inside the bamboo. Due to high-water content on peat are recorded, hypothetically, the high-water content in peat and its quasi-solid properties provide the potential for buoyancy generation. Otherwise, combined raft bamboo can make the load distribute uniformly in the ground.

Furthermore, by combining the abovementioned buoyant Archimedes concepts and literature, a little study will be introduced by using principles of the system floating method by Polyvinyl chloride (PVC) tube installed beneath the embankment by authors. PVC tubes are chosen as a medium for trapping the gas since the tube has a similar hollow shape to bamboo. They are known that air is less dense compared to water.

Due to the condition of peat which is high-water content, this research develops to review and apply the customizations of floating roads construction on peat soil by taking into consideration of the buoyancy force of water towards air or lighter gases to simulate and reflect the upward forces from water and translated to the stability and reducing the impact of settlement.

Helium gas has a molecular mass of approximately seven times less than air and air is less dense than water. Hence, Helium gas proposed injected into PVC tube via customized highpressure injection nipple. This proposal (Fig 15) expected able to simulate and reflect the upward forces, thus translating to the stability and reducing the impact of settlement to the embarkment. Various construction technique, especially road design, has been carried out to support embankment over peat deposit without risking bearing failures, but the settlement of these embankment remained excessively large for many years. This fact is related to the shear strength of peat soil. 


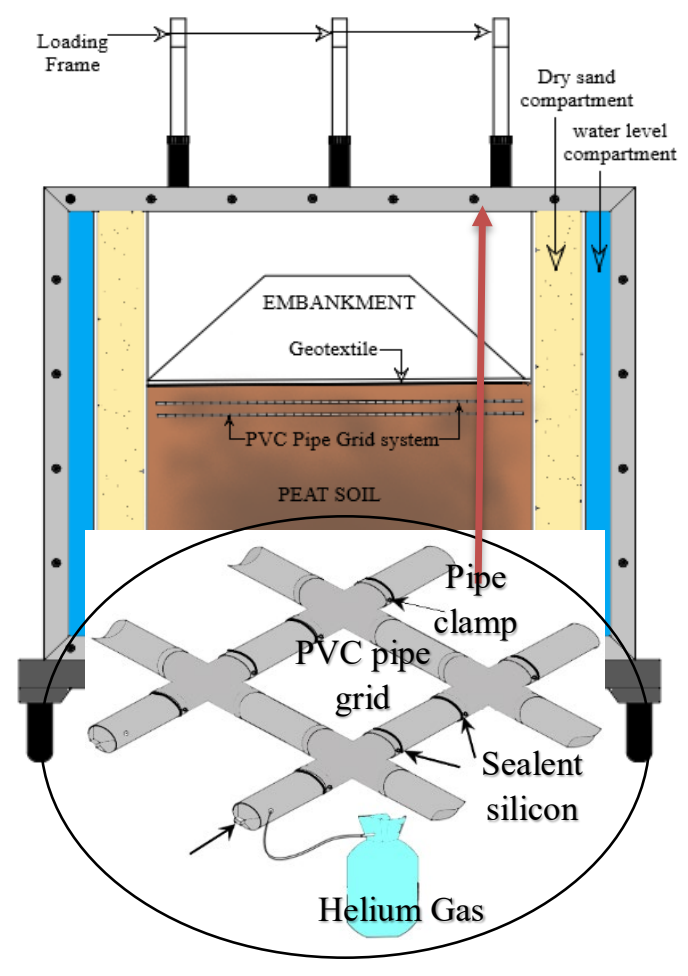

PVC end cap plug

Fig.15 Schematic diagram of Gas-Tube application

\section{ACKNOWLEDGMENTS}

The author wishes to give thanks and acknowledge where this research was supported by University Malaysia Sabah (UMS), under Acculturation Grant Scheme SGA0090-2019, Application of Helium Gas Tube for Road Embankment Design on Peat Soil.

\section{REFERENCES}

[1] Huat B. B. K., Prasad A., Asadi A., and Kazemian S, Geotechics of Organic Soil and Peat. CRC Press/Balkelma, (2014), 265pp

[2] Kazemian S., Huat B. B. K., Prasad A, and Barghchi M., "A State Of Art Review Of Peat: Geotechnical Engineering Perspective,” Int. J. Phys. Sci., vol. 6, no. 8, pp. 1974-1981, 2011, doi: $10.5897 /$ IJPS1 1.396.

[3] Deboucha S., Hashim R., and Alwi A., "Engineering Properties Of Stabilized Tropical Peat Soils," Electron. J. Geotech. Eng., vol. 13 E, 2008.

[4] Kazemian S. Huat B. B. K. and Prasad A., (2011). Study of Peat Media on Stabilization of Peat by Traditional Binders, Int. J. Phys. Sci., 6(3): 476-481
[5] Yusoff, S. A. N. M. (2015). Soil Stabilization Using Lignin and Bio- Enzymes. Universiti Tun Hussein Onn Malaysia. Master Thesis.

[6] Zainorabidin, A. (2010). Static and Dynamic Characteristics of Peat with Macro and Micro Structure Perspective. University East London. $\mathrm{PhD}$ Thesis.

[7] Huat, B. B.K. 2004. Organic and Peat Soils Engineering. Universiti Putra Malaysia Press, Serdang, Malaysia, pp. 20-80

[8] Mohamad, H. M., Zainorabidin, A., Musta, B., Mustafa, M., Amaludin, A., Abdurahman, M., 2021. Compressibility Behaviour and Engineering Properties of North Borneo Peat Soil. Eurasian J. Soil Sci. DOI: 10.18393/ejss. 930620

[9] Zainorabidin, A. (2010). Static and Dynamic Characteristics of Peat with Macro and Microstructure Perspective. University East London. PhD Thesis.

[10] Adon, R., Bakar, I. Wijeyesekera, D. C., and Adnan. (2012). Overview of The Sustainable Uses of Peat Soil in Malaysia. Int. Journal of Integrated Engineering - Special Issue on ICONCEES. Vol. 4 No. 3. pp. 38-46

[11] Wetland International, Malaysia (2010). A Quick Scan of Peatlands in Malaysia. Project funded by the Kleine Natuur Initiatief Projecten, Royal Netherlands Embass

[12] Gunarso, P., Hartoyo, M., Agus, F., Killeen, T., 2013. Oil Palm and Land Use Change in Indonesia, Malaysia and Papua New Guinea. Report from the technical Panels ` 92 of the $2^{\circ}$ Greenhouse Gas Working Group of Roundtable on sustainable Palm oil (RSPO)

[13]Zainorabidin A., Mohamad H.M. (2016). A Geotechnical Exploration of Sabah Peat soil: Engineering Classifications and Field surveys. Electronic Journal of Geotechnical Engineering, 2016, 21(20), pp. 6671-6687.

[14] Zainorabidin A., Mohamad H.M., (2016). Preliminary Peat Surveys in Ecoregion delineation of North Borneo: Engineering Perspective. Electronic Journal of Geotechnical Engineering, 2016, 21(12), pp. 4485-4493.

[15] Mohamad H.M., Kasbi, B., Baba M., Adnan Z., Hardianshah S., Ismail S., "Investigating Peat Soil Stratigraphy and Marine Clay Formation Using the Geophysical Method in Padas Valley, Northern Borneo", Applied and Environmental Soil Science, vol. 2021, Article ID 6681704, 12 pages, 2021.

[16] Magnan, J. P. (1980) "Classification Geotechnique Des Sols: 1- A Propos De La Classification LPC," Bulletin de Liaison des Laboratories des Ponts et Chaussees, Paris, 1924.

[17]ASTM Standard D 5715- 00

[18]Zainorabidin, A., Wijeyesekera, D. C., and 
Mohd Masirin, M. I. (2007). Comparative Study of British and Malaysian Peat Soils Pertaining to Geotechnical Characterization.

[19] Kogure K., (1998), Consolidation and Settlement of Peat Under Loading, International Symposium on Probelematic Soil, October 28-30,1998, the Japanese geotechnical society.

[20] Munro, R., (2004), "Dealing with Bearing Capacity Problems on Low Volume Roads Constructed on Peat. ROADEX n.p. 5-29,3463.

[21] Rahman, J. A. and Chan, C. M., (2014). Effect of the moisture content at different decomposition level of peat. Journal of Civil Engineering 2014, 4(3A): 59-62

[22]Zainorabidin A., and Wijeyesekera D.C., "Geotechnical Characteristics of Peat," Proc. Adv. Comput. Technol. 3rd Annu. Conf., no. January, pp. 71-78, 2008

[23] Kifli A. Z., Noor S., Taib L., and Chung W. C., "Physical Properties of Tropical Sibu Peat," pp. 5273-5287, 2017.

[24] Mohammad H. M., Zainorabidin A., "Engineering Properties of Integrated Tropical Peat Soil in Malaysia," J. Geotech. Eng., vol. 22, no. May 2017, pp. 1-9, 2017,

[25] Hobbs, N. B. (1986). Mire Morphology and the Properties and Behaviour of Some British and Foreign Peats. Q. I Eng. Geol., London, 19(1): 7-80.

[26] Edil T.B, Mochtar N.E (1984). Prediction of Peat Settlement. Proc. Sediment. Consolidation Models Symp. Prediction Validation, ASCE, San Fransisco, California, pp. 411-424.

[27] Mohamad, H.M., Adnan, Z., Razali, S.N.M., Zolkefle, S.N.A. (2020). Assessment for applicability of microwave oven in rapid determination of moisture content in peat soil. Journal of Engineering Science and Technology, 2020, 15(3), pp. 2110-2118.

[28] Atemin HH (2012). Study on Consolidation and Permeability Properties of Tropical Peat Universiti Tun Hussein Onn Malaysia: Degree's Thesis, 2012.

[29]Zainorabidin A, Nursyahidah S., Ismail B, . \& Seth, N. F. binti M. (2015). An Investigation of Soil Volume Changes at Four Dimensional Points of Peat Soil Sample in Parit Nipah and Pontian. Applied Mechanics and Materials,773-774, 1491-1496.

[30] Aminu Ibrahim, Huat B.K, Afshin A., Haslinda Nahazanan (2014), "Foundation and Embankment Construction in Pear: An Overview.

[31] Vincent T.C K, Public Works Department Sarawak, "Peat and organic Soils Challenges in Road Construction in Sarawak: Jkr Sarawak experience" (2016), 15th international peat congress 2016, abstract no: a-306

[32] Anghel, Stanciu \& Colţ, Oana \& Lungu, Irina, "Evolution of the design methods for reinforced soil works" january 2007, Acta Technica Napocensis: Civil Engineering \& Architecture.

[33] Waruwu A, and Susanti R. D (2015), "Behavior of Soil Peat with Reinforcement of Bamboo Grid," IOSR J. Eng. www.iosrjen.org ISSN, vol. 05, no. 11, pp. 1-29, 2015

[34] Standard terminology for Geosynthetics, in ASTM D4439-17, ed. (American Society for Testin and Materials, United States, 2017), p. 6

[35] Paulus P. Rahardjo, Chapter 31 The Use of Bamboo and Bakau Piles for Soil Improvements and Application of Pile Raft System for The Construction of Embankment on Peats and Soft Soils (2005), Editor(s): Buddhima Indraratna, Jian Chu, Elsevier GeoEngineering Book Series, Volume3, 2005, Pages 899-921

[36] Toh, C. T., Chua, S. K., Chee, S. K., Yeo, S. C. \& Chock, E. T. (1990). Peat replacement trial at Machap Proc. Seminar on Geotechnical Aspects of the North-South Expressway, Kuala Lumpur, 5- 6 Nov

[37] C. T. Toh, S. K. Chee, C. H. Lee \& S. H. Wee h (1994). Geotextile-Bamboo Fascine Mattress for Filling over Very Soft Soils in Malaysia. Geotextile and Geomembranes 13 (1994) 357 36, 1994 Elsevier Science Limited

[38] Fazirah Sapar, Nurul Irah and Matlan, Siti Jahara and Mohamad, H.M, and Alias, Rohaya and Ibrahim, Aniza, A Study on Physical and Morphological Characteristics of Tropical Peat in Sabah (2020). International Journal of Advanced Research Advanced Research, In Engineering and Technology, 11(11), 2020, pp. 542-553

[39] Aazokhi W., Maulana, and Husny Halim (2017), "Settlement Estimation of Peat Reinforced with Bamboo Grid Under Embankment", International Review of Civil Engineering (I.RE.C.E.), Vol. 8, N. 6, November 2017, ISSN 2036 - 9913

[40] Marto, A and Othman, B.A (2011), "The Potential Use of Bamboo as Green Material for Soft Clay Reinforcement System” 2011 International Conference on Environment Science and Engineering, IPCBEE vol.8 (2011) (C) (2011) IACSIT Press, Singapore

[41] Aazokhi Waruwu, Husni Halim, and Johan Adolf Putra Buulolo "Effect of loading sequences on the compressibility behavior of peat soil reinforced by bamboo grids."

[42] Aazokhi Waruwu, Maulana, and Husny Halim (2017), "Settlement Estimation of Peat Reinforced with Bamboo Grid Under Embankment", International Review of Civil 
Engineering (I.RE.C.E.), Vol. 8, N. 6, November 2017, ISSN 2036 - 9913

[43] Maulana, \& Azwar, \& Susanti, R.D. \& Waruwu, Aazokhi. (2018). Potential of bamboo pile as reinforcement of peat soil under embankment. ARPN Journal of Engineering and Applied Sciences. 13. 52-56

[44] Irsyam M., Krisnanto S and Wardhani, S.P.R. Instrumented Full Scale Test and Numerical Analysis to Investigate Performance of Bamboo Pile-Mattress System as Soil Reinforcement for Coastal Embankment on Soft Clay. Geotechnical Engineering for Disaster Mitigation and Rehabilitation Liu, Deng and Chu (eds) 2008 Science Press Beijing and Springer-Verlag GmbH Berlin Heidelberg (2008).

[45] Khatib A. (2009) Bearing Capacity of Granular Soil overlying Soft Clay Reinforced with BambooGeotextile Composite at the Interface. Ph.D Thesis, Universiti Teknologi Malaysia.

[46] Marto, Aminaton \& Othman, Bakhtiar Affandy \& Kasim, Fauziah \& Hj. Bakar, Ismail. (2012). Comparison of Field Performance between Bamboo-Geotextile Composite Embankment and High Strength Geotextile Embankment. Advanced Materials Research. 587. 77-80. 10.4028/www.scientific.net/AMR.587.77.

[47] Zainorabidin, A., Mohamad, H.M. (2015). Preand post-cyclic behavior on monotonic shear strength of Penor peat. Electronic Journal of Geotechnical Engineering, 2015, 20(16), pp. 6927-6935.

[48] Tioh, Ngee Heng \& Sai, Low. (2016). bamboogeotextile buoyant system for hefty construction over deep soft subgrade. Journal of Built Environment, Technology and Engineering. (1) 262-272.
[49] Krause, João \& Ghavami, Khosrow. (2009). "Transversal reinforcement in bamboo culms".Proceedings of the 11th International Conference on Non-conventional Materials and Technologies (NOCMT 2009). 6-9 September 2009, Bath, UK.

[50] Mohamad, H., Zainorabidin, A., Musta, B., Mustafa, M., Amaludin, A., Abdurahman, M., 2021. Compressibility behaviour and engineering properties of North Borneo Peat Soil. Eurasian J. Soil Sci. 10(3): 259-268.

[51] Islam M.S, Hashim R., (2008a). Use of Machintosh Probe Test For Field Investigation in Peat Soil. Proceeding of the International Conference,

[52] Islam S, Hashim R (2008b). Engineering properties of peat soils in peninsular Malaysia. J. Appl. Sci., 8(22)

[53] Duraisamy, Youventharan \& Sulaiman, Arif \& Othman, Rokiah. (2020). Ultimate bearing capacity of peat treated with cement columns in physical model. IOP Conference Series: Materials Science and Engineering. 712. 012043. 10.1088/1757-899X/712/1/012043.

[54] Sa'don N. M., Abdul Karim, A. R. W. Jaol, and Wan Lili W. H. (2014). Sarawak Peat Characteristics and Heat Treatment. UNIMAS E-Journal of Civil Engineering, Vol 5(issue 3) December 2014.

[55]Zulwali, Azrul \& Zainorabidin, Adnan \& Masirin, Mohd. (2016). physical properties of peat in sibu, sarawak. Proceedings of Soft Soils 2016, September 27-28th 2016.

Copyright $(\mathcal{C}$ Int. J. of GEOMATE All rights reserved, including making copies unless permission is obtained from the copyright proprietors 